\title{
KEEFEKTIFAN SEKOLAH DILIHAT DARI DELAPAN STANDART NASIONAL PENDIDIKAN DI WILAYAH EKS KARESIDENAN SURAKARTA
}

\author{
SCHOOL EFFECTIVENESS BASED ON 8 NATIONAL STANDARDS OF EDUCATION IN \\ THE FORMER RESIDENCY OF SURAKARTA
}

\author{
Parwanto \\ Pusat Penelitian Kebijakan Pendidikan dan Kebudayaan, Balitbang Kemdikbud \\ syelana@yahoo.com
}

Naskah diterima: 02/06/2016, direvisi akhir: 14/06/2016, disetujui: 22/06/2016

\begin{abstract}
Abstrak: Penelitian ini bertujuan untuk mengetahui gambaran keefektifan sekolah dilihat dari delapan standar nasional pendidikan. mengetahui tingkat ketecapaian keefektifan sekolah dilihat dari delapan standar nasional pendidikan dan mengetahui dari kedelapan standart nasional pendidikan butir mana disetiap standart yang masih perlu mendapatkan perhatian secara serius. Metode penelitian yang digunakan adalahmetode survai yakni upaya mengumpulkan informasi dari responden yang merupakan contoh dengan menggunakan kuesioner yang terstruktur. Populasi dari penelitian ini adalah jumlah satuan pendidikan Sekolah Mengengah Pertama (SMP) sebanyak 349 sekolah yang bersatatus sekolah negeri yang menyebar di wilayah eks karesidenan Surakarta. Sampel diambil sebanyak 172 sekolah dengan pendekatan area probability sampling. Instrumen yang digunakan dalam penelitian ini merupakan kuesioner tertutup dengan skala likert. Setelah data terkumpul kemudian dianalisis dengan pendekatan kuantitatif secara deskriptif. Hasil penelitian menunjukkan bahwa dilihat dari standar isi; standar proses; standar kompetensi kelulusan; standar pendidikan dan tenaga kependididkan; standar sarana dan prasarana ; standar pengelolaan; standar pembiayaan; dan standar penilaian sudah cukup baik. Ketercapaian delapan standar nasional pendidikan seluruh sekolah sampel sudah mencapai tingkat yang cukup tinggi yakni di atas 90\%, kendati masih ada beberapa dari sub butir standart yang masih perlu lebih diperbaiki
\end{abstract}

Kata Kunci: keefektifan, standar nasional pendidikan.

Abstract: The aim of this research is to discover the school effectiveness seen from eight components of standards of national education. From these eight components, we will find out which components still need to be regenerated. This research is using survey method by structured questionnaire to gather information from respondents. The population is 349 Government Junior High Schools in a region of ex Surakarta Residence. Total of samples from population is 172 schools, using area probability sampling approach. To collect the data, we used closed questionnaire with Likert scale as the instrument. After all data collected, then we analyze it descriptively with quantitative approach. The result shown that all the components of standards of national education, including content standards; process standards; competence of graduates standards; educational standards and human resource standards; facilities standards; management standards; funding standards; and assesment standards are fairly good. The achievement of eight standards of national education from all sample schools already achieved high level, i.e. above than 90\%. But still there are several sub components needs to be regenerated.

Keywords: effectiveness, standards of national education 


\section{PENDAHULUAN}

Kemendikbud telah mengembangkan sebuah pendekatan yang komprehensif untuk meningkatkan mutu, relevansi, dan daya saing pendidikan. Pendekatan komprehensif ini adalah dikembangkannya standar nasional pendidikan dan diberlakukannya otonomi yang cukup luas pada satuan pendidikan. Atas dasar tersebut telah diterbitkan PP No.19 Tahun 2005 tentang Standar Nasional Pendidikan yang mengamanahkan dibentuknya Badan Standar Nasional Pendidikan dengan tugas utama mengembangkan 8 (delapan) Standar Nasional Pendidikan (SNP), yaitu: (1) Standar Isi, (2) Standar Kompetensi Lulusan, (3) Standar Pendidik dan Tenaga Kependidikan, (4) Standar Sarana dan Prasarana, (5) Standar Penilaian, (6) Standar Proses, (7) Standar Pengelolaan, dan (8) Standar Biaya. Delapan standar ini menjadi acuan dalam penjaminan mutu pendidikan yang dilaksanakan dalam konteks otonomi satuan pendidikan.

Upaya telah banyak dilakukan oleh pemerintah untuk meningkatkan mutu pendidikan. Sebagaimana diketahui bahwa mutu pendidikan ditengarai merupakan salah satu cara untuk meningkatkan kualitas tenaga kerja. Mutu pendidikan yang baik, salah satunya tercermin dalam perolehan nilai ujian merupakan indikasi sekolah efektif. Mendikbud menyampaikan bahwa ada fenomena penurunan nilai ujian nasional tingkat SMP yang cukup significant untuk mata perlajaran matematika. Lebih lanjut Mendikbud menyampaikan bahwa rerata UN
SMP tahun 2016 adalah 58,57, sementara tahun 2015 rerata menjadi 62,18 atau turun 1,54 point. Sedangkan rerata nilai UN MTs tahun ini 59,06 turun dari tahun lalu 60,97. Adapun di SMP Terbuka nilai reratanya 48,36 atau turun dari 51,04 pada tahun lalu (Kompas, 11 Juni 2016).

Sehubungan dengan itu, UU No: 20 Tahun 2003 tentang Sisdiknas, serta UU No: 15 Tahun 2005 tentang Guru dan Dosen, Kementerian Pendidikan dan Kebudayaan (Kemendikbud) mengambil berbagai kebijakan terobosan yang mendasar dan berskala besar selama periode 2005-2007. Dalam jangka menengah dan panjang kebijakan ini diharapkan akan berdampak besar pada peningkatan dan pemerataan akses pendidikan, peningkatan mutu, relevansi, dan daya saing pendidikan, serta penguatan tata kelola, akuntabilitas, dan citra publik pendidikan.

Satu hal yang perlu diingat bahwa setiap kebijakan pendidikan akan berimplikasi langsung terhadap ruang lingkup persekolahan. Kebijakan yang terlalu administratifsentralistik yang diberlakukan oleh dinas pendidikan baik berasal dari pusat maupun di daerah akan menghambat kreativitas sekolah, bahkan hal itu bisa menyebabkan sekolah menjadi tidak dinamis akibat kesalahan interpretasi kebijakan. Selama orde baru dinilai kinerja birokrasi dinas pendidikan masih rendah karena selalu memainkan peran di depan sehigga menyulitkan lembaga persekolahan untuk mencapai keefektifan yang diinginkan. 
Patricia (2004:6) mengkaji sekolah efektif dengan membandingkan ukuran output yang didapat dengan output yang ditargetkan antara lain dalam bentuk: 1) etos kerja atau budaya mengenai pendidikan dan kenyamanan sekolah; 2) tingkat ekspektasi pada murid; 3) penetapan standar termasuk karakteristik sekolah; 4) pengambilan keputusan dan profesionalisme para guru; 5) pengaturan yang jelas mengenai tugas-tugas/ pekerjaan rumah, kelakuan para murid di sekolah dan sebagainya; 6) kepemimpinan (manajemen sekolah) dan 7) partisipasi peran serta para staf, masyarakat dan unsur lainnya). Selanjutnya Towsend(1994:38) mengartikan sekolah efektif sebagai (1) mampu mendemonstrasikan kebolehannya mengenai seperangkat kriteria (2) menetapkan sasaran yang jelas dan upaya untuk mencapainya (3) adanya kepemimpinan yang kuat (4) adanya hubungan yang baik antara sekolah dan orangtua siswa pengembangan staf dan iklim sekolah yang kondusif untuk belajar. Dalam memaknai sekolah efektif lebih lanjut Scheerens(1992:39) menyatakan sekolah efektif bercirikan (1) kepemimpinan yang kuat (2) penekanan pada pencapaian kemampuan dasar (3) adanya lingkungan yang nyaman (4) harapan yang tinggi pada prestasi siswa dan (5) penilaian secara rutin mengenai program yang dibuat oleh siswa.

Berdasarkan uraian dan penjelasan di atas kiranya perlu dilakukan suatu kajian yang mencermati tentang keefektifan delapan standart nasional pendidikan di tingkat satuan pendidikan.

\section{Rumusan Masalah}

Berdasarkan latar belakang masalah di atas maka dapat dirumuskan permasalahan sebagai berikut:

1. Bagaimana gambaran keefektifan sekolah dilihat dari delapan standar nasional pendidikan?

2. Sejauh mana tingkat ketercapaian keefektifan sekolah dilihat dari delapan standar nasional pendidikan?

3. Dari ke delapan standart nasional pendidikan butir mana disetiap standart yang masih perlu mendapatkan perhatian secara serius?

\section{Tujuan Penelitian}

Berdasarkan perumusan masalah di atas maka tujuan dari penelitian ini adalah mengetahui hal-hal sebagai berikut:

1. Mengetahui gambaran keefektifan sekolah dilihat dari delapan standar nasional pendidikan

2. Mengetahui tingkat ketecapaian keefektifan sekolah dilihat dari delapan standarnasional pendidikan

3. Mengetahui dari kedelapan standart nasional pendidikan butir mana disetiap standart yang masih perlu mendapatkan perhatian secara serius 


\section{KAJIAN LITERATUR}

\section{Pengertian Keefektifan}

Keefektifan merupakan ukuran pada suatu unit organisasi apakah mampu melaksanakan tugas-tugas manajerial yang dapat dilaksanakan dengan berhasil mencapai tujuan lembaga (Yukl, 2005:5). Sedangkan menurut Koontz (2004:8) Effectiveness is the achievement of objevtives. Artinya keefektifan diukur dengan tingkat keberhasilan dalam mencapai tujuan dengan kegiatan yang dilakukan.Suatu kegiatan dikatakan efektif bila telah mencapai tujuan yang ditentukan. Kegiatan dimaksud dikatakan efisien bila prosesnya memuaskan pelaksana, sehingga menjadi pendorong untuk mencapai tujuan yang hendak dicapai. Keefektifan dari usaha kerja sama antar individu atau unit kerja berkaitan erat dengan pelaksanaan tugas untuk mencapai suatu tujuan dalam suatu sistem yang didominasi dengan pandangan dapat memenuhi kebutuhan sistem dimaksud. Sedangkan efisiensi dari suatu sistem kerja adalah hasil gabungan efisiensi dari upaya setiap individu. Jelasnya bahwa keefektifan dari kelompok/organisasi adalah bila tujuan organisasi tersebut dapat dicapai sesuai dengan kebutuhan yang direncanakan (Newstrom, 1985: 216). Terkait dengan ini (Balitbang Dikbud 1995:11) lebih mempertegas perbedaan antara efisiensi dan efektivitas (keefektifan). Efisiensi didefinisikan sebagai suatu keadaan dimana tingkat output (keluaran) secara optimal dapat dihasilkan dengan menggunakan komposisi input (masukan) yang minimal. Sementara itu, keefektifan berkenaan dengan penilaian tingkat pencapaian tujuan (kuantitaif dan kualitatif).

Berdasarkan uraian di atas bahwa organisasi dapat dikatakan efektif apabila pencapaian tujuan sesuai dengan rencana yang dibuat berdasarkan kebijakan organisasi. Keefektifan organisasi dapat dilihat sejauh mana anggota organisasi tersebut melaksanakan tugas pokoknya atau pencapaian semua sasaran. Apabila tujuan suatu kegiatan yang telah direncanakan dapat diwujudkan maka dapat dikatakan bahwa pegawai bekerja secara efektif dan memiliki prestasi baik. Sedangkan apabila terdapat akibat yang tidak diinginkan dari proses kegiatan tersebut, maka berarti kegiatan dimaksud kurang efektif.

Keefektifan biasanya terkait dengan kriteria waktu untuk menunjukkan hasil tindakan dalam kurun waktu tertentu (Suwarto:1991: 9-11). Pendapat lain menyebutkan bahwa keefektifan berkaitan erat dengan pencapaian unjuk kerja secara maksimal, yaitu dalam arti pencapaian target yang berkaitan dengan kualitas, kuantitas dan waktu. Keterkaitan ini menunjukkan pada suatu ukuran yang menyatakan seberapa jauh tujuan telah dipenuhi semenjak proses hingga akhir kegiatan (Mulyasa: 2004: 132-133). Sementara itu menurut (Robbins: 2008: 20)

Effectiveness refer to the successful achievement of organizational goals. Thus effectiveness has been described as a measure of wheater managers are "doing the right things", whereas efficiency gauges the extent 
to which managers are "doing things right". A company is effective when it achieves its objectives. When it fails to achieveits objectives because they were poorly chosen, the plan for achieving them was poorly designed or executed, or the hostility of the competitive environment was greatce than the company had anticipated, the firm is ineffective.

Konsep keefektifan menurut Robbins di atas menyangkut pencapaian tujuan organisasi secara sukses, diartikan sebagai suatu ukuran bahwa tindakan yang dilakukan manajer adalah benar. Efisiensi menyangkut seberapa jauh para manajer melakukan hal-hal yang benar. Suatu perusahaan dikatakan efektif bila tercapai tujuannya. Sebaliknya perusahaan dikatakan tidak efektif apabila gagal mencapai tujuannya. Kegagalan pencapaian tujuan disebabkan karena kekeliruan di dalam menetapkan tujuan, merumuskan atau melaksanakan rencana untuk mencapai tujuan tersebut.Prokopenko (1987:5) mengatakan bahwa: Effectiveness is the degree to which goals are attained. Artinya bahwa keefektifan merupakan pencapaian terhadap tujuan yang diinginkan.

Uraian di atas menjelaskan bahwa keefektifan merupakan ukuran yang memberikan gambaran seberapa jauh target yang dapat dicapai, mengarah kepada pencapaian yang maksimal yaitu pencapaian target yang berkaitan dengan kualitas, kuantitas dan waktu. Keefektifan adalah seberapa baik pekerjaan yang dilakukan, sejauh mana tindakan yang dilakukan menghasilkan keluaran sesuai dengan yang diharapkan. Ini berarti bahwa apabila suatu tindakan dapat diselesaikan dengan perencanaan baik waktu, biaya maupun mutunya maka dapat dikatakan efektif.

Keefektifan suatu organisasi dicapai melalui keefektifan individual anggota organisasi dan keefektifan kelompok dalam organisasi tersebut. Keefektifan individual merupakan landasan utama bagi terbentuknya keefektifan kelompok, karena individu tidak bekerja seorang diri. Tumbuh dan berkembangnya keefektifan kelompok merupakan sinergi dari keefektifan individuindividu yang bekerjasama dalam sebuah kelompok. Selanjutnya keefektifan berbagai kelompok dalam organisasi akan bersinergi membentuk keefektifan organisasi.

\section{Pengukuran Keefektifan Sekolah}

Lembaga persekolahan sebagai suatu organisasi atau institusi pendidikan juga bertujuan mengoptimalisasikan sumberdaya, pengelolaan dan pengendalian. Oleh karena itu perlu adanya profesionalisme manajemen sekolah, yang secara teoritis akan bisa mewujudkan keefektifan sekolah. Maekenzie dalam kajiannya tentang School Culture (Komariah dan Triatna, 2005:35) mengemukakan bahwa:

"The literate on school culture make it clear that effective schools, school that demonstrate high standards of achievement in academics, have a culrure characterized by a well-defined set of goals that all member of the school administration, faculty, and student-value and promote". 
Sejalan dengan itu, Koster (1999:2) mengkaji keefektifan sekolah dilihat dari korelasi antara input sekolah, kepuasan kerja guru, partisipasi orangtua siswa dan iklim sekolah dengan hasil pengajaran. Dari kajian ini diperoleh temuan terdapat korelasi yang positif dan signifikan antara berbagai variabel yang dimaksud.

Keefektifan merupakan suatu dimensi tujuan manajemen yang berfokus pada hasil, sasaran, dan target yang diharapkan. Sekolah yang efektif adalah sekolah yang menetapkan keberhasilan pada input, proses, output, dan outcome yang ditandai dengan berkualitasnya komponen-komponen sistem tersebut. Dengan demikian, keefektifan sekolah bukan sekedar pencapaian sasaran atau terpenuhinya berbagai kebutuhan untuk mencapai sasaran, tetapi berkaitan erat dengan saratnya komponenkomponen sistem dengan mutu, dengan kata lain ditetapkannya pengembangan mutu sekolah.

Asas terpenting dan menjadi landasan bergerak dalam pengelolaan pendidikan menuju sekolah efektif adalah pernyataan bahwa "semua anak dapat belajar". Hal ini mengisyaratkan pada kita bahwa sekolah merupakan wahana yang menyediakan tempat yang terbaik bagi anak untuk belajar, a place for better learning. Artinya, semua upaya manajemen dan kepemimpinan yang terjadi di sekolah diarahkan bagi usaha membuat seluruh peserta didik belajar. Apabila mencari relevansi lain sehubungan dengan pernyataan di atas maka sekolah efektif dapat dimaknai sebagai sekolah yang mengorganisasikan dan memanfaatkan semua sumber daya yang dimilikinya untuk menjamin semua siswa (tanpa memandang ras, jenis kelamin, maupun status sosial ekonomi) biasa mempelajari materi kurikulum yang esensial di sekolah.

Keefektifan adalah ukuran yang menyatakan sejauh mana sasaran/tujuan (kuantitas, kualitas, dan waktu) telah dicapai. Dalam bentuk persamaan, keefektifan adalah sama dengan hasil nyata dibagi hasil yang diharapkan. Sekolah efektif menunjukkan kesesuaian antara hasil yang dicapai dengan hasil yang diharapkan.

Berdasarkan uraian di atas keefektifan sekolah menunjukkan adanya proses perekayasaan berbagai sumber dan metode yang diarahkan pada terjadinya pembelajaran di sekolah secara optimal. Dengan cara yang agak beda keefektifan sekolah merujuk pada pemberdayaan semua komponen sekolah sebagai organisasi tempat belajar berdasarkan tugas pokok dan fungsinya masing-masing dalam struktur program dengan tujuan agar siswa belajar dan mencapai hasil yang telah ditetapkan, yaitu memiliki kompetensi. Selanjutnya keefektifan sekolah sebagai sebuah studi juga diungkap dengan mengkaji faktor input, proses, output/outcome dan hubungan antara faktor-faktor tersebut yang merupakan telaah terhadap keberadaan sekolah pada tingkat mikro. Hal ini telah dibuktikan secara empiris diberbagai negara, yang menunjukkan bahwa studi keefektifan sekolah telah banyak membantu dalam memecahkan 
masalah pendidikan termasuk peningkatan mutu pendidikan (Murni: 2005: 2).

\section{Standar Nasional Pendidikan}

Keefektifan sekolah juga dapat diharapkan untuk mencapai standar nasional pendidikan yang telah ditetapkan. Standar nasional pendidikan adalah kriteria minimal tentang sistem pendidikan di seluruh wilayah hukum Negara Kesatuan Republik Indonesia (PP No: 19 Tahun 2005 tentang standar Nasional Pendidikan). Senada dengan itu, dihubungkan dengan sembilan hal yang menjadi ciri sekolah efektif (Squires, et.al, 1983: 145) yakni: a) adanya standar disiplin yang berlaku bagi kepala sekolah, guru, siswa dan karyawan di sekolah; b) memiliki suatu keteraturan dalam rutinitas kegiatan di sekolah; c) mempunyai standar prestasi sekolah yang sangat tinggi; d) siswa diharapkan mampu mencapai tujuan yang telah direncanakan; e) siswa diharapkan lulus dengan menguasai pengetahuan akademik; f) adanya penghargaan bagi siswa yang berprestasi; g) siswa berpendapat kerja keras lebih penting dari faktor keberuntungan dalam meraih prestasi; $h$ ) para siswa diharapkan mempunyai tanggung jawab yang diakui secara umum; dan i) kepala sekolah mempunyai program in service, pengawasan, supervisi, serta menyediakan waktu untuk membuat rencana bersama para guru sehingga memungkinkan adanya umpan balik demi keberhasilan prestasi akademik.
Standar nasional pendidikan terdiri dari: 1) standar isi; 2) standar proses; 3) standar kompetensi kelulusan; 4) standar pendidikan dan tenaga kependididkan; 5) standar sarana dan prasarana; 6) standar pengelolaan; 7) standar pembiayaan; 8) standar penilaian pendidikan. Lebih jauh peraturan pemerintah tersebut menjelaskan bahwa Standar isi adalah ruang lingkup materi dan tingkat kompetensi yang dituangkan dalam kriteria tentang kompetensi tamatan, kompetensi bahan kajian, kompetensi mata pelajaran, dan silabus pembelajaran yang harus dipenuhi oleh peserta didik pada jenjang dan jenis pendidikan tertentu. Standar proses adalah standar nasional pendidikan yang berkaitan dengan pelaksanaan pembelajaran pada satu satuan pendidikan untuk mencapai standar kompetensi lulusan. Selanjutnya Standar kompetensi lulusan adalah kualifikasi kemampuan lulusan yang mencakup sikap, pengetahuan, dan keterampilan. Standar pendidik dan tenaga kependidikan adalah kriteria pendidikan prajabatan dan kelayakan fisik maupun mental, serta pendidikan dalam jabatan. Kemudian Standar sarana dan prasarana adalah standar nasional pendidikan yang berkaitan dengan kriteria minimal tentang ruang belajar, tempat berolahraga, tempat beribadah, perpustakaan, laboratorium, bengkel kerja, tempat bermain, tempat berkreasi dan berekreasi, serta sumber belajar lain, yang diperlukan untuk menunjang proses pembelajaran, termasuk penggunaan teknologi informasi dan komunikasi. Standar pengelolaan adalah standar nasional 
pendidikan yang berkaitan dengan perencanaan, pelaksanaan, dan pengawasan kegiatan pendidikan pada tingkat satuan pendidikan, kabupaten/kota, provinsi, atau nasional agar tercapai efisiensi dan efektivitas penyelenggaraan pendidikan. Sedangkan Standar pembiayaan adalah standar yang mengatur komponen dan besarnya biaya operasi satuan pendidikan yang berlaku selama satu tahun. Standar penilaian pendidikan adalah standar nasional pendidikan yang berkaitan dengan mekanisme, prosedur, dan instrumen penilaian hasil belajar peserta didik.

\section{METODE PENELITIAN}

Penelitian ini menggunakan metode Survai yakni upaya mengumpulkan informasi dari responden yang merupakan contoh dengan menggunakan kuesioner yang terstruktur (Masri Singarimbun,1995:56). Populasi dari penelitian ini adalah jumlah satuan pendidikan Sekolah Mengengah Pertama (SMP) sebanyak 349 sekolah yang bersatatus sekolah negeri yang menyebar di wilayah eks karesidenan Surakarta. Selanjutnya teknik pengambilan sampel dilakukan secara bertahap dengan Cluster Sampling atau Area Sampling yakni teknik sampling daerah yang digunakan untuk menentukan bila objek yang diteliti sangat luas (Sugiyono, 2006:121). Sebagaimana diketahui wilayah eks Karesidenan Surakarta terdiri dari satu pemerintah kota (pemkot) dan 6 pemerintah kabupaten (pemkab) yakni Kota Surakarta, Kabupaten Sragen, Kabupaten Karanganyar, Kabupaten Sukoharjo,
Kabupaten Wonogiri, Kabupaten Klaten dan Kabupaten Boyolali.

Jumlah sampel sekolah menengah pertama sebagai unit analisis dalam penelitian ini diambil dengan menggunakan kaidah yang dikembangkan oleh Isaac dan Michael dengan toleransi kesalahan 5\% (Sugiyono, 2006:126) sebanyak 172 sekolah.

Instrumen yang akan digunakan untuk menjaring data dan informasi dalam penelitian ini berupa angket/kuesioner tentang keefektifan sekolah yang merupakan refleksi dari kinerjanya. Terdapat beberapa pendekatan untuk menilai kinerja seseorang, sebagaimana dikemukakan Oliva (1985: 434), "A fully developed program of teacher appraisalconsists of three components: selfevaluation, formative evaluation, and summativeevaluation”. Sedangkan Robbins (2003: 275) juga menegaskan bahwa penilaian kinerja dapat dilakukan oleh atasan langsung, rekan kerja, dan evaluasi diri. Data variabel keefektifan sekolah ini diperoleh dan ditelusuri ataupun direkonstruksi sedemikian rupa yang kemudian dipersepsikan oleh kepala sekolah.

Sebelum instrumen penelitian digunakan, terlebih dahulu diuji validitas dan reliabilitasnya. Pengujian validitas dilakukan dengan menghitung koefesien korelasi antara skor butir soal dengan skor total (rhitung) yang terdapat dalam satu variabel berdasarkan data yang diperoleh. Rumus yang digunakan dalam perhitungan tersebut adalah korelasi Product Moment (Sugiyono, 2007:356): 


$$
\begin{array}{cl}
\mathrm{r}_{\mathrm{i}}= & \multicolumn{1}{c}{\mathrm{n} \sum \mathrm{X}_{\mathrm{i}} \mathrm{Y}_{\mathrm{i}}-\left(\sum \mathrm{X}_{\mathrm{i}}\right)\left(\sum \mathrm{Y}_{\mathrm{i}}\right)} \\
& \sqrt{\left[\mathrm{n} \sum \mathrm{X}_{\mathrm{i}}^{2}-\left(\sum \mathrm{X}_{\mathrm{i}}\right)^{2}\right]\left[\mathrm{n}\left(\sum \mathrm{Y}_{\mathrm{i}}^{2}-\left(\sum \mathrm{Y}_{\mathrm{i}}\right)^{2}\right]\right.} \\
\mathrm{r}_{\mathrm{i}}= & \begin{array}{l}
\text { koefesien korelasi skor butir dengan } \\
\text { skor total }
\end{array} \\
\mathrm{n}= & \text { jumlah responden } \\
\mathrm{X}= & \text { skor butir } \\
\mathrm{Y}= & \text { skor total yang diperoleh dari } \\
& \text { penjumlahan skor butir }
\end{array}
$$

Dari hasil pengujian validitas ternyata semua butir valid, selanjutnya dihitung koefesien reliabilitas menggunakan data butir soal yang dinyatakan valid berdasarkan hasil uji validitas. Koefesien reliabilitas dihitung berdasarkan rumus Alpha Cronbach (Sugiyono, 2007: 365):

$$
\begin{aligned}
\mathrm{r}_{\mathrm{i}} & =\left\{\frac{\mathrm{k}}{(\mathrm{k}-1)}\right\} 1-\frac{\sum \mathrm{s}_{\mathrm{i}}}{\frac{2}{\mathrm{~s}_{\mathrm{t}}}} \\
\mathrm{K} & =\text { mean kuadrat antara subyek } \\
\sum \mathrm{s}_{\mathrm{i}}{ }^{2} & =\text { mean kuadrat kesalahan } \\
\mathrm{st}^{2} & =\text { varians total }
\end{aligned}
$$

Setelah instrumen dinyatakan valid dan reliabel, kemudian dilakukan uji normalitas. Untuk menguji normalitas sebaran data digunakan rumus Chi Kuadrat, sedangkan bentuk rumusnya sebagai berikut.

$$
\left.\chi^{2}=\Sigma \frac{(\text { fo }-\mathrm{fh})}{\mathrm{fh}} \quad \text { (Sugiyono, } 2007: 81\right)
$$

Keterangan:

$\chi^{2}=$ Chi Kuadrat

fo $=$ Frekuensi observasi dari populasi

$\mathrm{fh}=$ Frekuensi yang diharapkan dalam populasi

Kriteria sebaran data normal bila: $\chi^{2}$ hitung $<\chi_{\text {tabel, }}^{2}$ sedangkan sebaran data tidak normal apabila $\chi^{2}$ hitung $>\chi_{\text {tabel. }}^{2}$

Berdasarkan hasil uji validitas dan reliabilitas serta normalitas menunjukkan hasil yang bisa dipertanggungjawabkan. Artinya bahwa item-item pernyataan pada variabel penelitian menunjukkan bahwa semua item pernyataannya dikatakan valid dan reliabel serta distribusi data mengikuti kaidah distribusi normal

Dari uji reliabilitas dilakukan dengan menggunakan bantuan alat pengolahan data Lisrel., ternyata hasilnya valid dan reliable dengan koefisien diatas 0,8 . Selanjutnya uji

\begin{tabular}{|c|c|c|c|c|c|}
\hline Dimes & Variabd & Skewses & Kurtesis & $\begin{array}{l}\text { P raho } \\
\text { St owroess } \\
\text { and } \\
\text { Kertonis }\end{array}$ & Kot. \\
\hline Sod Isi & \multirow{8}{*}{$\begin{array}{l}\text { Koofiktifan } \\
\text { Solkolah }\end{array}$} & -3.896 & 6.746 & 0.000 & Norma! \\
\hline Sod. Proses & & -4.021 & 7.136 & 0.000 & Normal \\
\hline $\begin{array}{l}\text { Sod Ko mpotonsi } \\
\text { Lahosen }\end{array}$ & & -4.143 & 7.443 & 0.000 & Normel \\
\hline $\begin{array}{l}\text { Sod. Poodidzan den } \\
\text { Tenagz Kopondidinan }\end{array}$ & & -4.396 & 8.000 & 0.000 & Normal \\
\hline $\begin{array}{l}\text { Sod Sarma dan } \\
\text { Pasarana }\end{array}$ & & -4.054 & 7.167 & 0.000 & Normal \\
\hline Sod Pongelolon & & -4.192 & 7.562 & 0.000 & Nermal \\
\hline Sod Pentisyzon & & $-3.46 ?$ & 5.335 & 0,000 & Nermal \\
\hline $\begin{array}{l}\text { Sod Ponilin } \\
\text { Pendidenan }\end{array}$ & & -4.081 & 7.278 & 0.000 & Normal \\
\hline
\end{tabular}
normalitas, menurut Hair (Ghozali dan Fuad, 2005: 36) bahwa suatu data dikatakan normal jika data tersebut mempunyai distribusi normal. Salah satu cara untuk mengetahui normalitas sebuah data bisa didasarkan pada nilai skewness dan kurtosis-nyayakni jika nilai skewness kurang dari dua dan kurtosis kurang dari tujuh, maka data adalah normal. Namun demikian, jika tidak maka dapat dilihat dari nilai $\mathrm{p}$ value-nya yang tidak boleh melebihi $\alpha=$ 0,05 sebagaimana table di bawah.

Tabel 1. Uji Nomalitas Data

Setelah data semuanya terkumpul kemudian diolah dan dianalisis. Pengolahan dilakukan dengan cara mengelompokkan jawaban respondenberdasarkan informasi yang diungkap (variabel) untuk selanjutnya 
dianalisis secara deskribtip. Jawaban responden terkait dengan keefektifan sekolah diungkap dengan skala linkert dan dikelompokkan menjadi sangat efektif diberi skor 4, efektif diberi skor 3, tidak efektif dengan skor 2 dan sangat tidak efektif dengan skor 1 serta dibuat frekuensinya. Selanjutnya setelah tersusun distribusi frekuensi tentang keefektifan sekolah, kemudian dibuat skor kriterium dan skor ketercapaian. Skor kriterium diperoleh dengan asumsi semua responden menjawab dengan skor maksimum atau nila 4 , sedangkan skor ketercapaian dicari dengan cara mengkonversi jawaban yang telah diberikan oleh responden. Setelah tahap konversi dilakukan kemudian dianalisis lebih lanjutdengan cara hasil bobot skor jawaban persepsi responden mengenai variabel yang dimaksud, yakni rata-rata skor dikaitkan dengan standar deviasi kemudian diklasifikasikan menjadi rendah, sedang dan tinggi. Pengklasifikasian ini dikategorikan dengan criteria sedang jika nilai rata-rata plus minus satu standar deviasi, kemudian criteria rendah jika nilai rata-rata minus dua standar deviasi, selanjutnya nilai rata-rata plus dua standar deviasi masuk kategori tinggi.

\section{HASIL DAN PEMBAHASAN}

Data penelitian keefektifan sekolah yang diperoleh dari jawaban para responden yakni kepala sekolah SMP sebanyak 172 sekolah akan disajikan dalam bentuk tabel.Pada penelitian ini penulis membuat pertanyaan atau pernyataan sebanyak108 pernyataan tentang keefektifan sekolahterkait dengan delapan standar nasional pendidikan yakni standar isi; standar proses; standar kompetensi kelulusan; standar pendidikan dan tenaga kependididkan; standar sarana dan prasarana; standar pengelolaan; standar pembiayaan; standar penilaian pendidikan.yang diukur dengan menggunakan skala Likert. Dalam mengukur standar isi dalam keefektifan sekolah di satuan pendidikan Sekolah Menengah Pertama (SMP) menggunakan alat ukur kuesioner melalui pemberian 9 pernyataan tertutup dalam bentuk skala likert kepada responden.

Hasil penelitian menunjukkan bahwa responden menjawab sangat efektif $(63,95 \%)$, efektif $32,75 \%$, tidak efektif $2,71 \%$ dan sangat tidak efektif $0,58 \%$ terhadap pernyataan yang diajukan dalam keefektifan sekolah berdasarkan standar isi. Berdasarkan jawaban responden di atas, selanjutnya dapat diketahui tingkat ketercapaian standar isi yang telah dilaksanakan.Tingkat ketercapaian dilakukan dengan membandingkan skor hasil hitungan dengan skor normatif (kriterium) seperti tabel berikut. 
Tabel 2. Tingkat Ketercapaian Standar Isi

\begin{tabular}{|c|l|c|c|c|}
\hline No & \multicolumn{1}{|c|}{ Butir Pernyataan tentang Standar Isi } & $\begin{array}{c}\text { Skor } \\
\text { Hitung }\end{array}$ & $\begin{array}{c}\text { Skor } \\
\text { Kriterium }\end{array}$ & $\begin{array}{c}\text { Keter- } \\
\text { capaian }\end{array}$ \\
\hline 1 & $\begin{array}{l}\text { Sekolah melakukan kegiatan tatap muka lebih dari 40 } \\
\text { menit/sks. }\end{array}$ & 5355 & 6192 & 86,48 \\
\hline 2 & $\begin{array}{l}\text { Jumlah jam pembelajaran Sekolah kurang dari 32 } \\
\text { sks/minggu }\end{array}$ & 5562 & 6192 & 89,82 \\
\hline 3 & Semua siswa lulus menamatkan SMP dalam tiga tahun & 5715 & 6192 & 92,29 \\
\hline 4 & $\begin{array}{l}\text { Beban belajar satu sks meliputi satu jam pembelajaran } \\
\text { tatap muka, satu jam penugasan terstruktur, dan satu jam } \\
\text { kegiatan mandiri tidak terstruktur.. }\end{array}$ & 5508 & 6192 & 88,95 \\
\hline 5 & Pelajaran IPS diajarkan "IPS Terpadu" & 5508 & 6192 & 88,95 \\
\hline 6 & Minggu efektif belajar/semester kurang 34 minggu. & 5535 & 6192 & 86,48 \\
\hline 7 & Minggu efektif belajar/semester lebih 38 minggu. & 5598 & 6192 & 90,40 \\
\hline 8 & $\begin{array}{l}\text { Pelajaran IPA diajarkan berupa fisika, biologi, dan kimia } \\
\text { merupakan "IPA Terpadu". }\end{array}$ & 5679 & 6192 & 91,71 \\
\hline 9 & $\begin{array}{l}\text { Kurikulum memuat 10 mata pelajaran, muatan lokal, dan } \\
\text { pengembangan diri. }\end{array}$ & 5706 & 6192 & 92,15 \\
\hline & Rata-rata skor dan Ketercapaian & $\mathbf{5 5 7 4}$ & 6192 & 90,01 \\
\hline
\end{tabular}

Dari tabel di atas menunjukkan bahwa standar isi dapat diklasifikasikan pada kategori tinggi $(90,01 \%) . H a l$ ini menunjukkan bahwa keefektifan sekolah di satuan pendidikan Sekolah Menengah Pertama (SMP) berdasarkan standar isi telah terlaksana dengan baik. Berdasarkan hasil bobot skor jawaban persepsi responden mengenai variabel, maka dapat diketahui bahwa pernyataan pada itemitem variabel yang dapat dilakukan pembenahan adalah item-item pernyataan nomor 1 tentang sekolah melakukan kegiatan tatap muka lebih dari 40 menit/sks, pernyataan tentang jumlah jam pembelajaran Sekolah kurang dari 32 sks/minggu, pernyataan tentang beban belajar satu sks meliputi satu jam pembelajaran tatap muka, satu jam penugasan terstruktur, dan satu jam kegiatan mandiri tidak terstruktur, pernyataan tentang Pelajaran IPS diajarkan "IPS Terpadu" dan pernyataan mengenai minggu efektif belajar/semester kurang 34 minggu. Pernyataan pada item-item ini memberikan kontribusi kecil (di bawah ratarata bobot skor 5574). Prioritas utama yang perlu dibenahi adalah pernyataan pada item nomor 1 dengan skor 5355 yakni sekolah melakukan kegiatan tatap muka lebih dari 40 menit/sks. Hal ini bisa dimaknai bahwa pendistribusian beban kerja guru masih banyak yang harus diperbaruhi, sehingga bebannya menjadi lebih optimal disamping sebagai syarat mutlak sertifikasi guru.

\section{Keefektifan Sekolah Berdasarkan Standar Proses}

Dalam mengukur standar proses dalam keefektifan sekolah di satuan pendidikan Sekolah Menengah Pertama (SMP) menggunakan alat ukur kuesioner melalui pemberian 12 pernyataan tertutup dalam bentuk skala likert kepada responden dan diperoleh hasil bahwa responden menjawab sangat efektif $(67,05 \%)$, efektif $30,62 \%$, tidak efektif $1,74 \%$ dan sangat tidak efektif $0,58 \%$ 
terhadap pernyataan yang diajukan dalam keefektifan sekolah berdasarkan standar prosesBerdasarkan jawaban responden, selanjutnya dapat diketahui tingkat ketercapaian standar proses yang telah dilaksanakan.

Tingkat ketercapaian dilakukan dengan membandingkan skor hasil hitungan dengan skor normatif (kriterium). Dari tabel di bawah menunjukkan bahwa standar proses dapat diklasifikasikan pada kategori tinggi $(91,03 \%) . H a l$ ini menunjukkan bahwa keefektifan sekolah di satuan pendidikan Sekolah Menengah Pertama (SMP) berdasarkan standar proses telah terlaksana dengan baik.

Berdasarkan hasil bobot skor jawaban persepsi responden mengenai variabel, maka dapat diketahui bahwa pernyataan pada itemitem variabel yang dapat dilakukan pembenahan adalah item-item pernyataan nomor 1 tentang setiap mata pelajaran di Sekolah memiliki silabusnya (satuan pembelajaran, pernyataan tentang sekolahmemiliki Rencana Pelaksanaan Pembelajaran (RPP), pernyataan tentang RPP di Sekolah dapat medorong partisipasi aktif peserta didik. Pernyataan tentang setiap peserta didik di Sekolah memiliki budaya membaca dan menulis, pernyataan tentang setiap pihak terkait di Sekolah mentaati peraturan yang ada dan pernyataan mengenai pimpinan sekolah senantiasa mengunjungi kelas secara rutin. 
Tabel 3 Tingkat Ketercapaian Standar Proses

\begin{tabular}{|c|l|c|c|c|}
\hline No & Butir Pernyataan tentang Standar Proses & $\begin{array}{c}\text { Skor } \\
\text { Hitung }\end{array}$ & $\begin{array}{c}\text { Skor } \\
\text { Kriterium }\end{array}$ & $\begin{array}{c}\text { Keter- } \\
\text { capaian }\end{array}$ \\
\hline 1 & $\begin{array}{l}\text { Setiap mata pelajaran di Sekolah memiliki } \\
\text { silabusnya (satuan pembelajaran). }\end{array}$ & 7464 & 8256 & 90,40 \\
\hline 2 & $\begin{array}{l}\text { Sekolahmemiliki Rencana Pelaksanaan } \\
\text { Pembelajaran (RPP) }\end{array}$ & 7512 & 8256 & 90,98 \\
\hline 3 & $\begin{array}{l}\text { RPP di Sekolah dapat medorong partisipasi } \\
\text { aktif peserta didik. }\end{array}$ & 7488 & 8256 & 90,69 \\
\hline 4 & $\begin{array}{l}\text { Setiap peserta didik di Sekolah memiliki } \\
\text { budaya membaca dan menulis }\end{array}$ & 7536 & 8256 & 91,27 \\
\hline 5 & $\begin{array}{l}\text { Setiap peserta didik di Sekolah berpartipasi } \\
\text { aktif dalam proses belajar. }\end{array}$ & 7428 & 8256 & 89,97 \\
\hline 6 & $\begin{array}{l}\text { Setiap pihak terkait di Sekolah } \\
\text { melaksanakan proses belajar mengajar } \\
\text { dengan tertib. }\end{array}$ & 7572 & 8256 & 91,71 \\
\hline 7 & $\begin{array}{l}\text { Minggu efektif belajar/semester lebih } 38 \\
\text { minggu. }\end{array}$ & 7680 & 8256 & 93,02 \\
\hline 8 & $\begin{array}{l}\text { Setiap pihak terkait di Sekolah } \\
\text { melaksanakan proses belajar mengajar } \\
\text { dengan disiplin }\end{array}$ & 7572 & 8256 & 91,71 \\
\hline 9 & Kenyamanan di Sekolah diwujudkan & 7572 & 8256 & 91,71 \\
\hline 10 & $\begin{array}{l}\text { Setiap pihak terkait di Sekolah mentaati } \\
\text { peraturan yang ada. }\end{array}$ & 7428 & 8256 & 89,97 \\
\hline 11 & $\begin{array}{l}\text { Proses pembelajaran di Sekolah dipantau } \\
\text { dan disupervisi. }\end{array}$ & 7560 & 8256 & 91,56 \\
\hline 12 & $\begin{array}{l}\text { Pimpinan Sekolah senantiasa mengunjungi } \\
\text { kelas secara rutin. }\end{array}$ & 7380 & 8256 & 89,38 \\
\hline & Rata-rata skor dan Ketercapaian & $\mathbf{7 5 1 6}$ & 8256 & 91,03 \\
\hline
\end{tabular}

Pernyataan pada item-item tersebut memberikan kontribusi kecil (di bawah ratarata bobot skor 7516). Kemudian prioritas utama yang perlu dibenahi adalah pernyataan pada item mengenai pimpinan sekolah senantiasa mengunjungi kelas secara rutin dengan skor 7380 urutan pertama paling kecil. Hal ini berarti kepemimpinan di sekolah masih perlu dicermati secara serius, karena kepemimpinan begitu kuat mempengaruhi kinerja organisasi sehingga rasional apabila keterpurukan pendidikan salah satunya disebabkan karena kinerja kepemimpinan yang tidak dapat menyesuaikan diri dengan perubahan dan juga tidak membuat strategi pendidikan yang adaptif terhadap perubahan.

\section{Keefektifan Sekolah Berdasarkan Standar}

\section{Kompetensi Lulusan}

Dalam mengukur standar kompetensi lulusan dalam keefektifan sekolah di satuan pendidikan Sekolah Menengah Pertama (SMP) menggunakan alat ukur kuesioner melalui pemberian 17 pernyataan tertutup dalam bentuk skala likert kepada responden.Hasil survey menunjukkan bahwa responden menjawab sangat efektif $(65,56 \%)$, efektif $31,57 \%$, tidak efektif $2,22 \%$ dan sangat tidak 
efektif $0,65 \%$ terhadap pernyataan yang diajukan dalam keefektifan sekolah berdasarkan standar kompetensi lulusan.

Berdasarkan jawaban responden, selanjutnya dapat diketahui tingkat ketercapaian standar kompetensi lulusan yang telah dilaksanakan.Tingkat ketercapaian dilakukan dengan membandingkan skor hasil hitungan dengan skor normatif (kriterium). Dari tabel dibawah menunjukkan bahwa standar kompetensi lulusan dapat diklasifikasikan pada kategori tinggi (90,50\%). Hal ini menunjukkan bahwa keefektifan sekolah di satuan pendidikan Sekolah Menengah Pertama (SMP) berdasarkan standar kompetensi lulusan telah terlaksana dengan baik

Tabel 4 Tingkat Ketercapaian Standar Kompetensi Lulusan

\begin{tabular}{|c|c|c|c|c|}
\hline No & $\begin{array}{c}\text { Butir Pernyataan tentang Standar kompetensi } \\
\text { Lulusan }\end{array}$ & $\begin{array}{c}\text { Skor } \\
\text { Hitung }\end{array}$ & $\begin{array}{c}\text { Skor } \\
\text { Kriterium }\end{array}$ & $\begin{array}{l}\text { Keter- } \\
\text { capaian }\end{array}$ \\
\hline 1 & $\begin{array}{l}\text { Setiap siswa yang lulus dari Sekolah mengamalkan } \\
\text { ajaran agama yang dianut sesuai dengan tahap } \\
\text { perkembangan remaja }\end{array}$ & 10744 & 11696 & 91,86 \\
\hline 2 & $\begin{array}{l}\text { Setiap siswa yang lulus dari Sekolah memahami } \\
\text { kekurangan dan kelebihan diri sendiri }\end{array}$ & 10489 & 11696 & 89,66 \\
\hline 3 & $\begin{array}{l}\text { Setiap siswa yang lulus dari Sekolah menunjukkan } \\
\text { sikap percaya diri }\end{array}$ & 10557 & 11696 & 90,26 \\
\hline 4 & $\begin{array}{l}\text { Setiap siswa yang lulus dari Sekolah mematuhi } \\
\text { aturan-aturan sosial yang berlaku dalam lingkungan } \\
\text { yang lebih luas }\end{array}$ & 10727 & 11696 & 91,71 \\
\hline 5 & $\begin{array}{l}\text { Setiap siswa yang lulus dari Sekolah menghargai } \\
\text { keberagaman agama, budaya, suku, ras, dan } \\
\text { golongan sosial ekonomi dalam lingkup nasional }\end{array}$ & 10795 & 11696 & 92,29 \\
\hline 6 & $\begin{array}{l}\text { Setiap siswa yang lulus dari Sekolah dapat mencari } \\
\text { dan menerapkan informasi dari lingkungan sekitar } \\
\text { dan sumber-sumber lain secara logis, kritis, dan } \\
\text { kreatif }\end{array}$ & 10268 & 11696 & 87,79 \\
\hline 7 & $\begin{array}{l}\text { Setiap siswa yang lulus dari Sekolah menunjukkan } \\
\text { kemampuan berpikir logis, kritis, kreatif, dan } \\
\text { inovatif }\end{array}$ & 10200 & 11696 & 87,20 \\
\hline 8 & $\begin{array}{l}\text { Setiap siswa yang lulus dari Sekolah menunjukkan } \\
\text { kemampuan belajar secara mandiri sesuai dengan } \\
\text { potensi yang dimilikinya }\end{array}$ & 10438 & 11696 & 89,24 \\
\hline 9 & $\begin{array}{l}\text { Setiap siswa yang lulus dari Sekolah dapat } \\
\text { mendeskripsi gejala alam dan sosial }\end{array}$ & 10438 & 11696 & 89,24 \\
\hline 10 & $\begin{array}{l}\text { Setiap siswa yang lulus dari Sekolah dapat } \\
\text { menganalisis dan memecahkan masalah dalam } \\
\text { kehidupan sehari-hari }\end{array}$ & 10829 & 11696 & 92,58 \\
\hline 11 & $\begin{array}{l}\text { Setiap siswa yang lulus dari Sekolah menerapkan } \\
\text { hidup bersih, sehat, bugar, aman, dan } \\
\text { memanfaatkan waktu luang }\end{array}$ & 10659 & 11696 & 91,13 \\
\hline 12 & $\begin{array}{l}\text { Setiap siswa yang lulus dari Sekolah dapat } \\
\text { berkomunikasi dan berinteraksi secara efektif dan } \\
\text { santun }\end{array}$ & 10574 & 11696 & 90,40 \\
\hline 13 & $\begin{array}{l}\text { Setiap siswa yang lulus dari Sekolah dapat } \\
\text { memahami hak dan kewajiban diri dan orang lain } \\
\text { dalam pergaulan di masyarakat }\end{array}$ & 10523 & 11696 & 89,97 \\
\hline
\end{tabular}




\begin{tabular}{|c|c|c|c|c|}
\hline No & $\begin{array}{c}\text { Butir Pernyataan tentang Standar kompetensi } \\
\text { Lulusan }\end{array}$ & $\begin{array}{c}\text { Skor } \\
\text { Hitung }\end{array}$ & $\begin{array}{c}\text { Skor } \\
\text { Kriterium }\end{array}$ & $\begin{array}{l}\text { Keter- } \\
\text { capaian }\end{array}$ \\
\hline 14 & $\begin{array}{l}\text { Setiap siswa yang lulus dari Sekolah dapat } \\
\text { menghargai adanya perbedaan pendapat }\end{array}$ & 10540 & 11696 & 90,11 \\
\hline 15 & $\begin{array}{l}\text { Setiap siswa yang lulus dari Sekolah dapat } \\
\text { menunjukkan kegemaran membaca dan menulis } \\
\text { naskah pendek sederhana }\end{array}$ & 10608 & 11696 & 90,69 \\
\hline 16 & $\begin{array}{l}\text { Setiap siswa yang lulus dari Sekolah dapat } \\
\text { menunjukkan keterampilan menyimak, berbicara, } \\
\text { membaca, dan menulis dalam bahasa Indonesia dan } \\
\text { bahasa Inggris sederhana }\end{array}$ & 10880 & 11696 & 93,02 \\
\hline 17 & $\begin{array}{l}\text { Setiap siswa yang lulus dari Sekolah dapat } \\
\text { menguasai pengetahuan yang diperlukan untuk } \\
\text { mengikuti pendidikan menengah }\end{array}$ & 10693 & 11696 & 91,42 \\
\hline & Rata-rata skor dan Ketercapaian & 10586 & 11696 & $\mathbf{9 0 , 5 0}$ \\
\hline
\end{tabular}

Berdasarkan hasil bobot skor dapat diketahui bahwa pernyataan pada item-item variabel yang dapat dilakukan pembenahan adalah item-item pernyataan tentang setiap siswa yang lulus dari sekolah memahami kekurangan dan kelebihan diri sendiri, pernyataan tentang setiap siswa yang lulus dari sekolah menunjukkan sikap percaya diri, pernyataan tentang setiap siswa yang lulus dari sekolah dapat mencari dan menerapkan informasi dari lingkungan sekitar dan sumbersumber lain secara logis, kritis, dan kreatif, pernyataan tentang setiap siswa yang lulus dari sekolah menunjukkan kemampuan berpikir logis, kritis, kreatif, dan inovatif, pernyataan tentang setiap siswa yang lulus dari sekolah menunjukkan kemampuan belajar secara mandiri sesuai dengan potensi yang dimilikinya, pernyataan tentang setiap siswa yang lulus dari sekolah dapat mendeskripsi gejala alam dan sosial, pernyataan tentang setiap siswa yang lulus dari sekolah dapat berkomunikasi dan berinteraksi secara efektif dan santun, pernyataan tentang setiap siswa yang lulus dari sekolah dapat memahami hak dan kewajiban diri dan orang lain dalam pergaulan di masyarakat dan pernyataan tentang setiap siswa yang lulus dari sekolah dapat menghargai adanya perbedaan pendapat. Pernyataan pada item-item ini memberikan kontribusi kecil (di bawah rata-rata bobot skor 10586). Sedangkan prioritas utama yang perlu dibenahi adalah pernyataan pada item mengenai siswa yang lulus dari sekolah menunjukkan kemampuan berpikir logis, kritis, kreatif, dan inovatif dengan skor 10200yang merupakan pernyataan pada item variabel dengan skor urutan pertama paling kecil. Artinya masih diperlukan metode pembelajaran yang aktif, kreatif dan inovatif serta menyenangkan sehingga bisa membentuk atau membekali peserta didik untuk berfikir logis dan kritis. 


\section{Keefektifan Sekolah Berdasarkan Standar Pendidik Dan Tenaga Kependidikan}

Dalam mengukur standar pendidikan dan tenaga kependidikan dalam keefektifan sekolah di satuan pendidikan Sekolah Menengah Pertama (SMP) menggunakan alat ukur kuesioner melalui pemberian 23 pernyataan tertutup dalam bentuk skala likert Berdasarkan jawaban responden pada tabel di atas, selanjutnya dapat diketahui tingkat ketercapaian standar pendidik dan tenaga kependidikan yang telah dilaksanakan.Tingkat ketercapaian dilakukan dengan membandingkan skor hasil hitungan dengan skor normatif (kriterium). Dari tabel di bawah menunjukkan bahwa standar pendidik dan tenaga kependidikan dapat diklasifikasikan pada kategori tinggi $(90,74 \%)$. Hal ini menunjukkan bahwa keefektifan sekolah di satuan pendidikan Sekolah Menengah Pertama (SMP) berdasarkan standar pendidik dan tenaga kependidikan telah terlaksana dengan baik.

Hasil penelitian menunjukkan bahwa responden menjawab sangat efektif $(66,05 \%)$, efektif $31,47 \%$, tidak efekti $1,90 \%$ dan sangat tidak efektif $0,58 \%$ terhadap pernyataan yang diajukan dalam keefektifan sekolah berdasarkan standar pendidikan dan tenaga kependidikan.

Tabel 5 Tingkat Ketercapaian Standar Pendidik Dan Tenaga Kependidikan

\begin{tabular}{|c|l|c|c|c|}
\hline No & $\begin{array}{l}\text { Butir Pernyataan tentang Standar Pendidik } \\
\text { dan Tenaga Kependidikan }\end{array}$ & $\begin{array}{c}\text { Skor } \\
\text { Hitung }\end{array}$ & $\begin{array}{c}\text { Skor } \\
\text { Kriterium }\end{array}$ & $\begin{array}{c}\text { Keter- } \\
\text { capaian }\end{array}$ \\
\hline 1 & $\begin{array}{l}\text { Guru memiliki kualifikasi akademik pendidikan } \\
\text { minimum diploma empat (D-IV) atau sarjana (S1) } \\
\text { program studi yang sesuai dengan mata pelajaran } \\
\text { yang diajarkan/diampu, dan diperoleh dari program } \\
\text { studi yang terakreditasi. }\end{array}$ & 14214 & 15824 & 89,82 \\
\hline 2 & $\begin{array}{l}\text { Guru memahami karakteristik peserta didikyang } \\
\text { berkaitan dengan aspek fisik, intelektual, sosial- } \\
\text { emosional, moral, spiritual, dan latar belakang } \\
\text { sosial-budaya. }\end{array}$ & 14260 & 15824 & 90,11 \\
\hline 3 & $\begin{array}{l}\text { Guru mengidentifikasi kesulitan belajar peserta } \\
\text { didik dalam mata pelajaran yang diampu. }\end{array}$ & 14375 & 15824 & 90,84 \\
\hline 4 & $\begin{array}{l}\text { Guru memahami berbagai teori belajar dan prinsip- } \\
\text { prinsip pembelajaran yang mendidik terkait dengan } \\
\text { mata pelajaranyang diampu. }\end{array}$ & 14444 & 15824 & 91,27 \\
\hline 5 & $\begin{array}{l}\text { Guru menerapkan berbagai pendekatan, strategi, } \\
\text { metode, dan teknik pembelajaran yang mendidik } \\
\text { secara kreatif dalam mata pelajaran yang diampu. }\end{array}$ & 14260 & 15824 & 90,11 \\
\hline 6 & $\begin{array}{l}\text { Guru memahami prinsip-prinsip pengembangan } \\
\text { kurikulum. }\end{array}$ & 14651 & 15824 & 92,58 \\
\hline 7 & Guru berperilaku jujur, tegas, dan manusiawi. & 14237 & 15824 & 89,97 \\
\hline 8 & $\begin{array}{l}\text { Guru berperilaku yang mencerminkan ketakwaan } \\
\text { dan akhlak mulia. }\end{array}$ & 14398 & 15824 & 90,98 \\
\hline 9 & Guru memahami kode etik profesi guru. & 14513 & 15824 & 91,71 \\
\hline 10 & Guru menerapkan kode etik profesi guru. & 14375 & 15824 & 90,84 \\
\hline & $\begin{array}{l}\text { Guru berperilaku sesuai dengan kode etik profesi } \\
\text { guru. }\end{array}$ & 14191 & 15824 & 89,68 \\
\hline
\end{tabular}




\begin{tabular}{|c|l|c|c|c|}
\hline No & $\begin{array}{l}\text { Butir Pernyataan tentang Standar Pendidik } \\
\text { dan Tenaga Kependidikan }\end{array}$ & $\begin{array}{c}\text { Skor } \\
\text { Hitung }\end{array}$ & $\begin{array}{c}\text { Skor } \\
\text { Kriterium }\end{array}$ & $\begin{array}{c}\text { Keter- } \\
\text { capaian }\end{array}$ \\
\hline 12 & $\begin{array}{l}\text { Guru menampilkan diri sebagai pribadi yang } \\
\text { mantap dan stabil. }\end{array}$ & 14145 & 15824 & 89,38 \\
\hline 13 & $\begin{array}{l}\text { Guru menampilkan diri sebagai pribadi yang } \\
\text { dewasa, arif, dan berwibawa }\end{array}$ & 14237 & 15824 & 89,97 \\
\hline 14 & $\begin{array}{l}\text { Guru menunjukkan etos kerja dan tanggung jawab } \\
\text { yang tinggi. }\end{array}$ & 14076 & 15824 & 88,95 \\
\hline 15 & Guru bekerja mandiri secara profesional. & 14122 & 15824 & 89,24 \\
\hline 16 & $\begin{array}{l}\text { Guru mengadministrasikan penilaian proses dan } \\
\text { hasil belajar secara berkesinambungan dengan } \\
\text { menggunakan berbagai instrumen. }\end{array}$ & 14490 & 15824 & 91,56 \\
\hline 17 & $\begin{array}{l}\text { Guru menganalisis hasil penilaian proses dan hasil } \\
\text { belajar untuk berbagai tujuan. }\end{array}$ & 14582 & 15824 & 92,15 \\
\hline 18 & Guru melakukan evaluasi proses dan hasil belajar. & 14605 & 15824 & 92,29 \\
\hline 19 & $\begin{array}{l}\text { Guru berperilaku yang dapat diteladani oleh peserta } \\
\text { didik dan anggota masyarakat di sekitarnya. }\end{array}$ & 14444 & 15824 & 91,27 \\
\hline 20 & $\begin{array}{l}\text { Guru bersikap inklusif dan objektif terhadap } \\
\text { peserta didik, teman sejawat dan lingkungan sekitar } \\
\text { dalam melaksanakan pembelajaran. }\end{array}$ & 14421 & 15824 & 91,13 \\
\hline 21 & $\begin{array}{l}\text { Guru berkomunikasi kepada semua secara santun, } \\
\text { empatik dan efektif. }\end{array}$ & 14191 & 15824 & 89,68 \\
\hline 22 & $\begin{array}{l}\text { Guru memahami standar kompetensi mata } \\
\text { pelajaran yang diampu. }\end{array}$ & 14421 & 15824 & 91,13 \\
\hline 23 & $\begin{array}{l}\text { Guru memanfaatkan teknologi informasi dan } \\
\text { komunikasi untuk pengembangan diri. }\end{array}$ & 14628 & 15824 & 92,44 \\
\hline & Rata-rata skor dan Ketercapaian & $\mathbf{1 4 3 6 0}$ & $\mathbf{1 5 8 2 4}$ & $\mathbf{9 0 , 7 4}$ \\
\hline
\end{tabular}

Item-item pernyataan yang masuk kategori rendah adalah pernyataan guru menampilkan diri sebagai pribadi mantap dan stabil, pernyataan guru menunjukkan etos kerja dan tanggung jawab yang tinggi, dan pernyataan guru bekerja mandiri secara profesional. Dengan demikian sudah barang tentu etos kerja guru perlu ditingkatkan dengan cara menumbuhkan sikap optimis yakni mengembangkan semangat dalam diri, memelihara sikap optimis yang telah dipunyai serta memotivasi diri untuk bekerja lebih maju.

\section{Keefektifan Sekolah Berdasarkan Standar Sarana Dan Prasarana}

Dalam mengukur standar sarana dan prasarana dalam keefektifan sekolah di satuan pendidikan Sekolah Menengah Pertama (SMP)

menggunakan alat ukur kuesioner melalui pemberian 10 pernyataan tertutup dalam bentuk skala likert kepada responden.Hasil penelitian menunjukkan bahwa responden menjawab sangat efektif $(70,81 \%)$,efektif $26,80 \%$, tidak efektif $1,80 \%$ dan sangat tidak efektif $0,58 \%$ terhadap pernyataan yang diajukan dalam keefektifan sekolah berdasarkan standar sarana dan prasarana. Berdasarkan jawaban responden, selanjutnya dapat diketahui tingkat ketercapaian standar sarana dan prasarana yang telah dilaksanakan. Tingkat ketercapaian dilakukan dengan membandingkan skor hasil hitungan dengan skor normatif (kriterium). Dari tabel di bawah menunjukkan bahwa standar sarana dan prasarana dapat diklasifikasikan pada kategori tinggi $(91,96 \%)$. Hal ini menunjukkan bahwa 
keefektifan sekolah di satuan pendidikan berdasarkan standar sarana dan prasarana telah Sekolah Menengah Pertama (SMP) terlaksana dengan baik.

Tabel 6 Tingkat Standar Sarana Dan Prasarana

\begin{tabular}{|c|l|c|c|c|}
\hline No & \multicolumn{1}{|c|}{$\begin{array}{c}\text { Butir Pernyataan tentang Standar } \\
\text { Sarana dan Prasarana }\end{array}$} & $\begin{array}{c}\text { Skor } \\
\text { Hitung }\end{array}$ & $\begin{array}{c}\text { Skor } \\
\text { Kriterium }\end{array}$ & $\begin{array}{c}\text { Keter- } \\
\text { capaian }\end{array}$ \\
\hline 1 & $\begin{array}{l}\text { Gedung sekolah telah memiliki struktur yang } \\
\text { stabil dan kukuh untuk menopang beban. }\end{array}$ & 6380 & 6880 & 92,73 \\
\hline 2 & $\begin{array}{l}\text { Gedung sekolah telah dilengkapi sistem } \\
\text { mencegah dan menanggulangi bahaya } \\
\text { kebakaran/petir. }\end{array}$ & 6440 & 6880 & 93,60 \\
\hline 3 & $\begin{array}{l}\text { Gedung sekolah mempunyai ventilasi udara dan } \\
\text { pencahayaan yang memadai. }\end{array}$ & 6430 & 6880 & 93,45 \\
\hline 4 & $\begin{array}{l}\text { Sekolah memiliki kebijakan program secara } \\
\text { tertulis mengenai pengelolaan sarana dan } \\
\text { prasarana. }\end{array}$ & 6340 & 6880 & 92,15 \\
\hline 5 & $\begin{array}{l}\text { Gedung sekolah dapat memenuhi kebutuhan air } \\
\text { bersihnya. }\end{array}$ & 6190 & 6880 & 89,97 \\
\hline 6 & $\begin{array}{l}\text { Gedung sekolahmemiliki sanitasi yang memadai } \\
\text { baik di dalam dan di luar bangunan gedung. }\end{array}$ & 6220 & 6880 & 90,40 \\
\hline 7 & $\begin{array}{l}\text { Gedung sekolah menggunakan bahan bangunan } \\
\text { yang aman bagi kesehatan pengguna bangunan } \\
\text { gedung. }\end{array}$ & 6200 & 6880 & 90,11 \\
\hline 8 & $\begin{array}{l}\text { Gedung sekolah telah dilengkapi dengan lampu } \\
\text { penerangan yang memadai untuk setiap ruangnya. }\end{array}$ & 6310 & 6880 & 91,71 \\
\hline 9 & Kelas sekolah di isi lebih 32 peserta didik. & 6370 & 6880 & 92,58 \\
\hline 10 & $\begin{array}{l}\text { Ruang kelas sekolah telah memadai untuk semua } \\
\text { siswa berdasarkan tingkatan. }\end{array}$ & 6390 & 6880 & 92,87 \\
\hline & Rata-rata skor dan Ketercapaian & $\mathbf{6 3 2 7}$ & 6880 & 91,96 \\
\hline
\end{tabular}

Berdasarkan hasil bobot skor jawaban persepsi responden mengenai variabel, maka dapat diketahui bahwa pernyataan pada itemitem variabel yang dapat dilakukan pembenahan adalah item-item pernyataan tentang gedung sekolah dapat memenuhi kebutuhan air bersihnya , pernyataan tentang gedung sekolah memiliki sanitasi yang memadai baik di dalam dan di luar bangunan gedung, pernyataan tentang gedung sekolah menggunakan bahan bangunan yang aman bagi kesehatan pengguna bangunan gedung dan tentang gedung sekolah telah dilengkapi dengan lampu penerangan yang memadai untuk setiap ruangnya. Pernyataan pada itemitem ini memberikan kontribusi kecil (di bawah rata-rata bobot skor 6327). Sedangkan prioritas utama yang perlu dibenahi adalah pernyataan tentang air bersih dengan skor 6190yang merupakan pernyataan pada item variabel dengan skor urutan pertama paling kecil.Seiring dengan kemajuan jaman dan meningkatkan kesejahteraan masyarakat, kebersihan merupakan kebutuhan dasar yang 
harus dipenuhi tak terkecuali pada lingkungan sekolah. Oleh karena itu, sudah sewajarnya kebersihan merupakan skala prioritas yang harus dipenuhi.

\section{Keefektifan Sekolah Berdasarkan Standar}

\section{Pengelolaan}

Dalam mengukur standar pengelolaan dalam keefektifan sekolah di satuan pendidikan

Sekolah Menengah Pertama

(SMP) menggunakan alat ukur kuesioner melalui pemberian 20 pernyataan tertutup dalam bentuk skala likert kepada responden.

Hasil penelitian menunjukkan bahwa responden menjawab sangat efektif $(66,60 \%)$, efektif $30,99 \%$, tidak efektif $1,83 \%$ dan sangat tidak efektif $0,58 \%$ terhadap pernyataan yang diajukan dalam keefektifan sekolah berdasarkan standar pengelolaan. Berdasarkan jawaban responden pada tabel di bawah, selanjutnya dapat diketahui tingkat ketercapaian standar pengelolaan yang telah dilaksanakan.Tingkat ketercapaian dilakukan dengan membandingkan skor hasil hitungan dengan skor normatif (kriterium). Dari tabel di bawah menunjukkan bahwa standar pengelolaan dapat diklasifikasikan pada kategori tinggi $(90,90 \%)$. Hal ini menunjukkan bahwa keefektifan sekolah berdasarkan standar pengelolaan telah terlaksana dengan baik

Tabel 7 Tingkat Ketercapaian Standar Pengelolaan

\begin{tabular}{|c|l|c|c|c|}
\hline No & \multicolumn{1}{|c|}{$\begin{array}{c}\text { Butir Pernyataan tentang Standar } \\
\text { Pengelolaan }\end{array}$} & $\begin{array}{c}\text { Skor } \\
\text { Hitung }\end{array}$ & $\begin{array}{c}\text { Skor } \\
\text { Kriterium }\end{array}$ & $\begin{array}{c}\text { Keter- } \\
\text { capaian }\end{array}$ \\
\hline 1 & $\begin{array}{l}\text { Sekolah telah memiliki visi serta } \\
\text { mengembangkannya. }\end{array}$ & 12440 & $\mathbf{1 3 7 6 0}$ & $\mathbf{9 0 , 4 0}$ \\
\hline 2 & Sekolah telah memiliki misi & 12540 & $\mathbf{1 3 7 6 0}$ & $\mathbf{9 1 , 1 3}$ \\
\hline 3 & $\begin{array}{l}\text { Misi Sekolah dikembangkan berdasarkan visi } \\
\text { yang telah ditetapkan sebelumnya }\end{array}$ & 12400 & $\mathbf{1 3 7 6 0}$ & $\mathbf{9 0 , 1 1}$ \\
\hline 4 & $\begin{array}{l}\text { Sekolah telah memiliki tujuan terkait dengan } \\
\text { proses pembelajaran. }\end{array}$ & 12060 & $\mathbf{1 3 7 6 0}$ & $\mathbf{8 7 , 6 4}$ \\
\hline 5 & $\begin{array}{l}\text { Tujuan di Sekolah dikembangkan berdasarkan } \\
\text { visi dan misi sekolah }\end{array}$ & 12260 & $\mathbf{1 3 7 6 0}$ & $\mathbf{8 9 , 0 9}$ \\
\hline 6 & $\begin{array}{l}\text { Semua elemen di Sekolah dapat menerima visi } \\
\text { dan misi yang telah ditetapkan. }\end{array}$ & 12440 & $\mathbf{1 3 7 6 0}$ & $\mathbf{9 0 , 4 0}$ \\
\hline 7 & $\begin{array}{l}\text { Semua elemen di Sekolah dapat memahami visi } \\
\text { dan misi yang telah ditetapkan. }\end{array}$ & 12700 & $\mathbf{1 3 7 6 0}$ & $\mathbf{9 2 , 2 9}$ \\
\hline 8 & $\begin{array}{l}\text { Semua elemen di Sekolah senantiasa berupaya } \\
\text { untuk mewujudkan visi, misi dan tujuan } \\
\text { sekolah. }\end{array}$ & 12680 & $\mathbf{1 3 7 6 0}$ & $\mathbf{9 2 , 1 5}$ \\
\hline 9 & $\begin{array}{l}\text { Sekolah telah memiliki rencana kerja jangka } \\
\text { menengah. }\end{array}$ & 12560 & $\mathbf{1 3 7 6 0}$ & $\mathbf{9 1 , 2 7}$ \\
\hline 10 & $\begin{array}{l}\text { Sekolah telah memiliki rencana kerja jangka } \\
\text { panjang. }\end{array}$ & 12400 & $\mathbf{1 3 7 6 0}$ & $\mathbf{9 0 , 1 1}$ \\
\hline 11 & $\begin{array}{l}\text { Semua pihak terkait di Sekolah dapat mengakses } \\
\text { rencana kerja jangka menengah sekolah. }\end{array}$ & 12560 & $\mathbf{1 3 7 6 0}$ & $\mathbf{9 1 , 2 7}$ \\
\hline 12 & \begin{tabular}{l} 
Sekolah telah memiliki rencana kerja tahunan. \\
\hline
\end{tabular} & 12620 & $\mathbf{1 3 7 6 0}$ & $\mathbf{9 1 , 7 1}$ \\
\hline
\end{tabular}




\begin{tabular}{|c|l|c|c|c|}
\hline No & \multicolumn{1}{|c|}{$\begin{array}{c}\text { Butir Pernyataan tentang Standar } \\
\text { Pengelolaan }\end{array}$} & $\begin{array}{c}\text { Skor } \\
\text { Hitung }\end{array}$ & $\begin{array}{c}\text { Skor } \\
\text { Kriterium }\end{array}$ & $\begin{array}{c}\text { Keter- } \\
\text { capaian }\end{array}$ \\
\hline 13 & $\begin{array}{l}\text { Sekolah memiliki suasana, iklim, dan } \\
\text { lingkungan pendidikan yang kondusif untuk } \\
\text { pembelajaran yang efisien. }\end{array}$ & 12680 & $\mathbf{1 3 7 6 0}$ & $\mathbf{9 2 , 1 5}$ \\
\hline 14 & $\begin{array}{l}\text { Sekolah dapat mengembangkan kurikulum } \\
\text { sekolah. }\end{array}$ & 12460 & $\mathbf{1 3 7 6 0}$ & $\mathbf{9 0 , 5 5}$ \\
\hline 15 & Sekolah memiliki kalender pendidikan & 12480 & $\mathbf{1 3 7 6 0}$ & $\mathbf{9 0 , 6 9}$ \\
\hline 16 & $\begin{array}{l}\text { Sekolah telah memiliki pedoman yang mengatur } \\
\text { berbagai aspek pengelolaan secara tertulis yang } \\
\text { mudah dibaca oleh pihak-pihak yang terkait }\end{array}$ & 12340 & $\mathbf{1 3 7 6 0}$ & $\mathbf{8 9 , 6 8}$ \\
\hline $\begin{array}{l}\text { Pedoman pengelolaan KTSP, kalender } \\
\text { pendidikan dan pembagian tugas pendidik dan } \\
\text { tenaga kependidikan di Sekolah dievaluasi } \\
\text { dalam skala tahunan, sementara lainnya } \\
\text { dievaluasi sesuai kebutuhan. }\end{array}$ & 12360 & $\mathbf{1 3 7 6 0}$ & $\mathbf{8 9 , 8 2}$ \\
\hline 18 & $\begin{array}{l}\text { Saya dapat menjamin mutu kegiatan } \\
\text { pembelajaran untuk setiap mata pelajaran dan } \\
\text { program pendidikan tambahan yang dipilihnya. }\end{array}$ & 12760 & $\mathbf{1 3 7 6 0}$ & $\mathbf{9 2 , 7 3}$ \\
\hline 19 & $\begin{array}{l}\text { Pimpinan, pendidik, dan tenaga kependidikan di } \\
\text { Sekolah semua mempunyai uraian tugas, } \\
\text { wewenang, dan tanggung jawab yang jelas } \\
\text { tentang keseluruhan penyelenggaraan dan } \\
\text { administrasi sekolah. }\end{array}$ & 12640 & $\mathbf{1 3 7 6 0}$ & $\mathbf{9 1 , 8 6}$ \\
\hline 20 & $\begin{array}{l}\text { Sekolah memiliki program pengawasan di } \\
\text { sekolah/madrasah didasarkan pada Standar } \\
\text { Nasional Pendidikan. }\end{array}$ & 12780 & $\mathbf{1 3 7 6 0}$ & $\mathbf{9 2 , 8 7}$ \\
\hline & $\begin{array}{l}\text { Rata-rata skor dan Ketercapaian } \\
\mathbf{1 2 5 0 8}\end{array}$ & $\mathbf{1 3 7 6 0}$ & $\mathbf{9 0 , 9 0}$ \\
\hline
\end{tabular}

Item-item pernyataan yang masuk kategori rendah adalah pernyataan sekolah telah memiliki tujuan terkait dengan proses pembelajaran, tujuan di Sekolah dikembangkan berdasarkan visi dan misi sekolah, dan pernyataan Pimpinan, pendidik, dan tenaga kependidikan di Sekolah semua mempunyai uraian tugas, wewenang, dan tanggung jawab yang jelas tentang keseluruhan penyelenggaraan dan administrasi sekolah.Sejalan dengan itu, visi pendidikan yang melekat pada institusi sekolah yang merupakan dinamisator instrumental sekolah sangat mempengaruhi kinerja sekolah dan sudah barang tentuharus diupayakan sedemikian rupa sehingga bekerja secara optimal.

\section{Keefektifan Sekolah Berdasarkan Standar Pembiayaan}

Dalam mengukur standar pembiayaan dalam keefektifan sekolah di satuan pendidikan Sekolah Menengah Pertama (SMP) menggunakan alat ukur kuesioner melalui pemberian 4 pernyataan tertutup dalam bentuk skala likert kepada responden.Hasil penelitian menunjukkan bahwa mayoritas responden menjawab sangat efektif $(65,12 \%)$, efektif 32 , $85 \%$, tidak efektif $1,45 \%$ dan sangat tidak efektif $0,58 \%$ terhadap pernyataan yang diajukan dalam keefektifan sekolah 
berdasarkan standar pembiayaan. Berdasarkan jawaban responden pada tabel di atas, selanjutnya dapat diketahui tingkat ketercapaian standar pembiayaan yang telah dilaksanakan. Tingkat ketercapaian dilakukan dengan membandingkan skor hasil hitungan dengan skor normatif (kriterium).Dari tabel di bawah menunjukkan bahwa standar pembiayaandapat diklasifikasikan pada kategori tinggi $(90,63 \%)$.Hal ini menunjukkan bahwa keefektifan sekolah di satuan pendidikan Sekolah Menengah Pertama (SMP) berdasarkan standar pembiayaan telah terlaksana dengan baik

Tabel 8 Tingkat Standar Pembiayaan

\begin{tabular}{|c|l|c|c|c|}
\hline No & \multicolumn{1}{|c|}{ Butir Pernyataan tentang Standar Pembiayaan } & $\begin{array}{c}\text { Skor } \\
\text { Hitung }\end{array}$ & $\begin{array}{c}\text { Skor } \\
\text { Kriterium }\end{array}$ & $\begin{array}{c}\text { Keter- } \\
\text { capaian }\end{array}$ \\
\hline 1 & $\begin{array}{l}\text { Sekolah mempunyai pedoman pengelolaan biaya } \\
\text { investasi dan operasional. }\end{array}$ & 2528 & 2752 & 91,86 \\
\hline 2 & $\begin{array}{l}\text { Sekolah dapat memenuhi semua biaya yang } \\
\text { dibutuhkan untuk operasional sekolah. }\end{array}$ & 2492 & 2752 & 90,55 \\
\hline 3 & $\begin{array}{l}\text { Pedoman pengelolaan biaya investasi dan } \\
\text { operasional Sekolah telah disusun } \\
\text { berdasarkan standar pembiayaan }\end{array}$ & 2484 & 2752 & 90,26 \\
\hline 4 & $\begin{array}{l}\text { Sekolah telah memiliki sistem informasi } \\
\text { manajemen mendukung administrasi } \\
\text { pendidikan yang efektif, efisien dan } \\
\text { akuntabel. }\end{array}$ & 2472 & 2752 & 89,82 \\
\hline \multicolumn{1}{|c|}{ Rata-rata skor dan Ketercapaian } & $\mathbf{2 4 9 4}$ & 2752 & 90,63 \\
\hline
\end{tabular}

Berdasarkan hasil bobot skor jawaban persepsi responden mengenai variabel, dapat diketahui bahwa pernyataan pada item-item variabel yang dapat dilakukan pembenahan adalah item-item pernyataan tentang Sekolah dapat memenuhi semua biaya yang dibutuhkan untuk operasional sekolah, pernyataan nomor 3 tentang Pedoman pengelolaan biaya investasi dan operasional Sekolah telah disusun berdasarkan standar pembiayaan dan pernyataan nomor 4 tentang Sekolah telah memiliki sistem informasi manajemen mendukung administrasi pendidikan yang efektif, efisien dan akuntabel. Pernyataan pada item-item ini memberikan kontribusi kecil (di bawah rata-rata bobot skor 2494). Prioritas utama yang perlu dibenahi adalah tentang sistem informasi manajemen mendukung administrasi pendidikan yang efektif, efisien dan akuntabel dengan skor 2472. Seiring dengan perkembangan teknologi informasi yang berekembang secara dinamis, maka sudah sewajarnya institusi sekolah sesegera mungkin lebih mengutamakan pengunaan sistem informasi manajemen menjadi lebih dikedepankan. 
Keefektifan Sekolah Berdasarkan Standar Penilaian Pendidikan

Dalam mengukur standar penilaian pendidikan dalam keefektifan sekolah di satuan pendidikan Sekolah Menengah Pertama (SMP) menggunakan alat ukur kuesioner melalui pemberian 10 pernyataan tertutup dalam bentuk skala likert kepada responden. Hasil penelitian menunjukkan bahwa responden menjawab sangat efektif $(65,58 \%)$, efektif $31,34 \%$, tidak efektif $2,50 \%$ dan sangat tidak efekti $0,58 \%$ terhadap pernyataan yang diajukan dalam keefektifan sekolah berdasarkan standar penilaian pendidikan. Berdasarkan jawaban responden pada tabel di bawah, selanjutnya dapat diketahui tingkat ketercapaian standar penilaian pendidikan yang telah dilaksanakan.Tingkat ketercapaian dilakukan dengan membandingkan skor hasil hitungan dengan skor normatif (kriterium).
Dari tabel di atas menunjukkan bahwa standar penilaian pendidikandapat diklasifikasikan pada kategori tinggi $(90,47 \%)$.Hal ini menunjukkan bahwa keefektifan sekolah di satuan pendidikan Sekolah Menengah Pertama (SMP) berdasarkan standar penilaian pendidikan telah terlaksana dengan baik.

Berdasarkan hasil bobot skor jawaban persepsi responden mengenai variabel, maka dapat diketahui bahwa pernyataan pada itemitem variabel yang dapat dilakukan pembenahan adalah item-item pernyataan tentang Sekolah telah memiliki kriteria kenaikan kelas bagi satuan pendidikan yang menggunakan sistem paket melalui rapat dewan pendidik, pernyataan tentang Penentuan kriteria program pembelajaran bagi satuan pendidikan yang menggunakan sistem kredit semester melalui rapat dewan pendidik.

Tabel 9 Tingkat Standar Penilaian Pendidikan

\begin{tabular}{|c|l|c|c|c|}
\hline No & \multicolumn{1}{|c|}{$\begin{array}{c}\text { Butir Pernyataan tentang Standar Penilaian } \\
\text { Pendidikan }\end{array}$} & $\begin{array}{c}\text { Skor } \\
\text { Hitung }\end{array}$ & $\begin{array}{c}\text { Skor } \\
\text { Kriterium }\end{array}$ & $\begin{array}{c}\text { Keter- } \\
\text { capaian }\end{array}$ \\
\hline 1 & $\begin{array}{l}\text { KKM (kelompok kerja matapelajaran) setiap mata } \\
\text { pelajaran telah memperhatikan karakteristik peserta } \\
\text { didik, karakteristik mata pelajaran, dan kondisi } \\
\text { satuan pendidikan melalui rapat dewan pendidik. }\end{array}$ & 6290 & 6880 & 91,42 \\
\hline 2 & $\begin{array}{l}\text { Sekolah telah memiliki kriteria kenaikan kelas bagi } \\
\text { satuan pendidikan yang menggunakan sistem paket } \\
\text { melalui rapat dewan pendidik. }\end{array}$ & 6010 & 6880 & 87,35 \\
\hline 3 & $\begin{array}{l}\text { Penentuan kriteria program pembelajaran bagi satuan } \\
\text { pendidikan yang menggunakan sistem kredit } \\
\text { semester melalui rapat dewan pendidik. }\end{array}$ & 5920 & 6880 & 86,04 \\
\hline 4 & $\begin{array}{l}\text { Penentuan nilai akhir kelompok mata pelajaran } \\
\text { estetika dan kelompok mata pelajaran pendidikan } \\
\text { jasmani, olah raga dan kesehatan melalui rapat } \\
\text { dewan pendidik dengan mempertimbangkan hasil } \\
\text { penilaian oleh pendidik. }\end{array}$ & 6180 & 6880 & 89,82 \\
\hline 5 & $\begin{array}{l}\text { Penentuan nilai akhir kelompok mata pelajaran } \\
\text { agama dan akhlak mulia dan kelompok mata }\end{array}$ & 6490 & 6880 & 94,33 \\
\hline
\end{tabular}




\begin{tabular}{|c|l|c|c|c|}
\hline No & \multicolumn{1}{|c|}{$\begin{array}{c}\text { Butir Pernyataan tentang Standar Penilaian } \\
\text { Pendidikan }\end{array}$} & $\begin{array}{c}\text { Skor } \\
\text { Hitung }\end{array}$ & $\begin{array}{c}\text { Skor } \\
\text { Kriterium }\end{array}$ & $\begin{array}{c}\text { Keter- } \\
\text { capaian }\end{array}$ \\
\hline & $\begin{array}{l}\text { pelajaran kewarganegaraan dan kepribadian } \\
\text { dilakukan melalui rapat dewan pendidik dengan } \\
\text { mempertimbangkan hasil penilaian oleh pendidik dan } \\
\text { nilai hasil ujian sekolah. }\end{array}$ & 6880 & 94,18 \\
\hline 6 & $\begin{array}{l}\text { Penyelenggaraan ujian sekolah dan menentukan } \\
\text { kelulusan peserta didik dari ujian sekolah/madrasah } \\
\text { sesuai dengan POS Ujian Sekolah bagi satuan } \\
\text { pendidikan penyelenggara UN. }\end{array}$ & 6480 & 6880 & 90,98 \\
\hline 7 & $\begin{array}{l}\text { Pelaporan hasil penilaian mata pelajaran untuk semua } \\
\text { kelompok mata pelajaran pada setiap akhir semester } \\
\text { kepada orang tua/wali peserta didik dalam bentuk } \\
\text { buku laporan pendidikan. }\end{array}$ & 6260 & 6880 & 89,38 \\
\hline 8 & $\begin{array}{l}\text { Pelaporan pencapaian hasil belajar tingkat satuan } \\
\text { pendidikan kepada dinas pendidikan kabupaten/kota. }\end{array}$ & 6150 & 6880 & 90,55 \\
\hline 9 & $\begin{array}{l}\text { Sekolah menerbitkan Surat Keterangan Hasil Ujian } \\
\text { Nasional (SKHUN) setiap peserta didik yang } \\
\text { mengikuti Ujian Nasional bagi satuan pendidikan } \\
\text { penyelenggara UN. }\end{array}$ & 6230 & 6880 & 90,69 \\
\hline 10 & $\begin{array}{l}\text { Sekolah menerbitkan ijazah setiap peserta didik yang } \\
\text { lulus dari satuan pendidikan bagi satuan pendidikan } \\
\text { penyelenggara UN. }\end{array}$ & 6240 & 60,47 \\
\hline & Rata-rata skor dan Ketercapaian & $\mathbf{6 2 2 5}$ & 6880 & \\
\hline
\end{tabular}

Selanjutnya pernyataan tentang penentuan nilai akhir kelompok mata pelajaran estetika dan kelompok mata pelajaran pendidikan jasmani, olah raga dan kesehatan melalui rapat dewan pendidik dengan mempertimbangkan hasil penilaian oleh pendidikdan pernyataan tentang Pelaporan pencapaian hasil belajar tingkat satuan pendidikan kepada dinas pendidikan kabupaten/kota. Pernyataan pada item-item ini memberikan kontribusi kecil (di bawah ratarata bobot skor 6225). Sedangkan prioritas utama yang perlu dibenahi adalah pernyataan mengenai Penentuan kriteria program pembelajaran bagi satuan pendidikan dengan skor 5920.Ketidaksepahaman tentang kriteria ini tidak bisa dibiarkan berkepanjangan karena bisa mempengaruhi kineja sekolah dalam arti luas. Oleh karena itu, perlu duduk bersama antar pihak sekolah (guru dan kepala sekolah) dengan dewan pendidikan serta difasilitasi oleh dinas pendidikan mencari solusi permasalahan ini.

\section{SIMPULAN DAN SARAN}

\section{Simpulan}

1. Keefektifan Sekolah dilihat dari standar isi; standar proses; standar kompetensi kelulusan; standar pendidikan dan tenaga kependididkan; standar sarana dan prasarana ; standar pengelolaan; standar pembiayaan; dan standar penilaian sudah cukup baik. Hanya saja masih terdapat dua standart yang ketercapaiannya masih berada dibawah $90 \%$ yakni standart pendidikan dan 
tenaga kependidikan serta standart pengelolaan.

2. Sub butir standart yang masih perlu diperbaiki Standar isi yakni sekolah melakukan kegiatan tatap muka lebih dari $40 \mathrm{menit} / \mathrm{sks}$ danminggu efektif belajar/semester kurang 34 minggu;Standar proses,pimpinan sekolah senantiasa mengunjungi kelas secara rutin; Standar kompetensi kelulusan,setiap siswa yang lulus dari sekolah menunjukkan kemampuan berpikir logis, kritis, kreatif, dan inovatif; Standar pendidikan dan tenaga kependididkan, guru bekerja mandiri secara profesional;Standar sarana dan prasarana, gedung sekolah dapat memenuhi kebutuhan air bersihnya;Standar pengelolaan,sekolah telah memiliki tujuan terkait dengan proses pembelajaran; Standar pembiayaan,sekolah telah memiliki sistem informasi manajemen mendukung administrasi pendidikan yang efektif, efisien dan akuntabel; Standar penilaian pendidikan,penentuan kriteria program pembelajaran bagi satuan pendidikan yang menggunakan sistem kredit semester melalui rapat dewan pendidik.

\section{Saran}

1. Keefektifan Sekolah dilihat dari standar isi; standar proses; standar kompetensi kelulusan; standar pendidikan dan tenaga kependididkan; standar sarana dan prasarana; standar pengelolaan; standar pembiayaan; dan standar penilaian dipertahankan dan jika mungkin lebih ditingkakan lagi.

2. Keefektifan sekolah dari aspek delapan standar tetap mempertahankan standar pendidik dan tenaga kependidikan terutama peningkatan kualitasnya serta memperbaiki standar pembiayaan pendidikan. Peningkatan standart kompetensi pendidik bias dilakukan melalui pengayaaan kemampuan pendidik dan perbaikan manajemen keuangan sekolah

3. Diperlukan gaya kepemimpinan kepala sekolah dan peran dinas pendidikan yang bisa menciptakan iklim sekolah yang kondusive sehingga bisa lebih meningkatkan kinerja kepala sekolah. 


\section{DAFTAR PUSTAKA}

Balitbang Dikbud. 1995. Efisiensi Pengelolaan Pendidikan. Jakarta: Pusinfot Balitbang Dikbud.

Ghozali, Imam dan Fuad. 2005. Structural Equation Modeling. Semarang: Badan Penerbit Universitas Diponegoro.

Gibson, Ivancevich, Donnelly. 2000. Organizations, Behavior, Structures, Process. ten edition Boston Massachusetts: The McGrawhill Companies, Inc.

Hadi, Sutrisno. 1994.Metodologi Research 2. Cetakan ke 15. Yogyakarta: Andi $\quad$ Offset.

Kinicki, Kreitner . 2005. Perilaku Organisasi. Jakarta: Salemba Empat.

Komariah, Aan dan Triatna, Cepi, 2005. Visionary Leadership Menuju Sekolah Efektif. Bandung: Bumi Aksara.

Koontz, Harold \& Weihrich, Heinz. 2004. Management. 11 ${ }^{\text {th }}$ Edition, Singapore: McGrawHill International.

Koster, Wayan. 1999. Studi Korelasional antara Input Sekolah, Kepuasan Kerja Guru, Partisipasi Orangtua Siswa dan Iklim Sekolah dengan Hasil Pengajaran SLTP di Jakarta. Jakarta: Program Pascasarjana Universitas Negeri Jakarta. Disertasi tidak dipublikasikan

Mulyasa, E 2004, Menjadi Kepala Sekolah Profesional. Bandung: Remaja Rosdakarya.

Murni, Sylvia. 2007, Pengaruh Karakteristik Sekolah, Partisipasi Masyarakat (komite sekolah), Iklim Sekolah dan Kemampuan Manajemen terhadap Keefektifan Sekolah.Jakarta: Disertasi tidak dipublikasikan

Newstrom dan Davis, 2002, Organizational Behavior, International Edition, New York: The McGraw Hill Companies.

Oliva, P.F. 1985. Supervision for Today's Schools. Second Edition. New York \& London: Longman;

Patricia C. Stetson dan Wm. Ray Heitzman. 2004. The Psychology of Learning and Teaching. New York: Arno Press

Prokopenko, Joseph, 1987. Productivity Management: A Practical Handbook. Switcherland : International Labour Organization.

Robbins, Stephen P. 2003, Essentials of Organizational Behavior, Seventh Edition, New Jersey: Upper Saddle River, Pearson Education Inc. 
Robbins, Stephen P. 2008. Organizational Behaviour: Concepts, Controversies, \& Applications. 13 ${ }^{\text {th }}$ Edition, New Jersey:Prentice-Hall. Inc.

Squires, Huitt, and Segars. 1983. Effective Scholl and Classrooms: Research and Best Perspective,Alexandria: Association for Supervision and Curricullum Development

Scheerens. 1992. Effective Schooling; Research, Theory and Practice. London: Cassel

Singarimbun, Masri dan Effendi, Sofian,1991, Metode Penelitian Survai. Jakarta:Penerbit LP3ES.

Sugiyono, 2006. Metode Penelitian Pendidikan, Pendekatan Kuantitatif, Kualitatif dan $\boldsymbol{R} \& \boldsymbol{D}$. Bandung: Alfabeta

Suwarto, FX. 1999. Perilaku Keorganisasian. Yogyakarta: Universitas Atmajaya.

Townsend.1994. Effective Scholling for The Community. London: Rauledge.

Yukl, Gary. 2005. Kepemimpinan dalam Organisasi. Edisi Kelima, Jakarta: PT Indeks Kelompok Gramedia.

Kompas, 11 Juni 2016. Hasil UN Gambarkan Realitas 